\title{
Malgorzata Dziembala
}

Uniwersytet Ekonomiczny w Katowicach

e-mail: malgorzata.dziembala@ue.katowice.pl

\section{POLITYKA WSPIERANIA INNOWACYJNOŚCI}

W BRAZYLII I W JEJ REGIONACH

\section{POLICY OF SUPPORTING INNOVATION IN BRAZIL} AND ITS REGIONS

DOI: $10.15611 / \mathrm{e} 21.2016 .3 .19$

JEL Classification: F0, 03.

Streszczenie: Brazylia jest jednym z krajów BRICS, którego gospodarka dynamicznie się rozwija. Przyczyniły się do tego wdrażane reformy. Podejmowane są także działania na rzecz kreowania nowoczesnego systemu innowacji. Jednakże, jak wynika z przeprowadzonej analizy, potencjał innowacyjny Brazylii wciąż nie jest dostateczny, a zarazem bardzo zróżnicowany przestrzennie. Niskie nakłady ponoszone na działalność $B+R$, niewielkie zaangażowanie pracowników naukowych we współpracę międzynarodową - to tylko niektóre z wyzwań, w obliczu których znalazła się Brazylia. Niska jest również innowacyjność przemysłu brazylijskiego, wciąż chronionego przed międzynarodową konkurencją. Celem artykułu jest analiza potencjału innowacyjnego Brazylii oraz przedstawienie polityki realizowanej na rzecz wspierania innowacyjności w tym kraju.

Slowa kluczowe: potencjał innowacyjny, system innowacji, działalność badawczo-rozwojowa.

Summary: Brazil is one of BRICS countries, with dynamically developing economy. It has been so due to the reforms implemented in this country. The measures are taken to create a modern system of innovation. However, as the analysis shows, the innovative potential of Brazil is still not sufficient, and also spatially diversified to a large extent. Low expenditure on $R \& D$, rich human resources but with insufficient qualifications, low motivation of scientists in international cooperation - these are just some challenges encountered by Brazil. The innovativeness of Brazilian industry, which is still protected from international competition, is also low. This article aims to analyze the innovation potential of Brazil and presents the implemented policy aimed to promote innovation in this country.

Keywords: innovation potential, innovation system, research and development activity. 


\section{Wstęp}

W ostatnich latach w Brazylii dokonały się znaczne przemiany społeczno-gospodarcze. W rezultacie poprawiły się wskaźniki dotyczące ubóstwa, polepszył dostęp społeczeństwa do edukacji, opieki zdrowotnej i sytuacja ekonomiczna. PKB na mieszkańca wzrósł z 7016,6 dol. w 2000 r. do 11 566,8 dol. w 2014 r. [OECD 2015, s. 17]. Makroekonomiczna stabilność tego kraju osiągnięta w połowie lat 90. przyczyniła się do pozytywnych przemian. Jednakże ostatnio pogarsza się sytuacja fiskalna Brazylii i następuje wzrost inflacji. W 2014 r. stopa inflacji w tym kraju wyniosła $6,4 \%$. Także dotychczasowa dynamika wzrostu gospodarczego uległa spowolnieniu. O ile w 2010 r. wzrost PKB wyniósł 7,6\%, o tyle w 2013 r. 2,7\%, a rok później stanowił zaledwie 0,1\% [OECD 2015, s. 14, 17]. Konieczne jest podejmowanie działań na rzecz poprawy produktywności w tym kraju, szczególnie poprzez działania ukierunkowane na rozwój i unowocześnienie przemysłu, co powinno przyczynić się także do pobudzania wzrostu gospodarczego. Przemysł tego kraju ma znaczny niewykorzystany potencjał, jednakże charakteryzuje się niską innowacyjnością. Także niedostateczny stan infrastruktury, niska presja konkurencyjna, fragmentaryczny system opodatkowania pośredniego, problemy z pozyskaniem pracowników o wysokich kwalifikacjach - to tylko niektóre z problemów wymagających pilnego rozwiązania w sektorze przemysłu w tym kraju [OECD 2015, s. 10$-11,14]$.

W Brazylii wdrażane są narodowe programy i inicjatywy ukierunkowane na tworzenie współczesnego narodowego systemu innowacji. Celem artykułu jest analiza potencjału innowacyjnego Brazylii oraz przedstawienie polityki realizowanej na rzecz wspierania innowacyjności w tym kraju. Poprzez działania na rzecz wspierania innowacyjności, również w sektorze przemysłu i poprawy jego produktywności, może nastąpić dynamiczny rozwój tego kraju.

\section{Innowacyjność Brazylii i jej regionów}

Brazylia dysponuje znacznym potencjałem ludnościowym, kraj ten bowiem zamieszkuje 200,4 mln osób, stanowiąc 2,8\% światowego potencjału ludnościowego (2013 r.) [UNESCO 2015, s. 25]. Udział tego kraju w światowym PKB w 2013 r. wyniósł 3\% [UNESCO 2015, s. 25]. W ostatnich kilkunastu latach Brazylia podlega przeobrażeniom społeczno-gospodarczym. Odsetek osób żyjących na granicy ubóstwa zmniejszył się z 13,3\% w 2009 r. do 7,4\% w 2014 r. [http://data.worldbank.org/ country/brazil]. Innowacje stanowią ważny czynnik przyczyniający się do wzrostu gospodarczego tego kraju. Jednakże podstawowe wskaźniki dotyczące działalności $\mathrm{B}+\mathrm{R}$ w Brazylii pokazują słabości jej potencjału innowacyjnego (tab. 1). Intensywność nakładów na B+R w tym kraju w latach 2007-2012 utrzymuje się na względnie stałym, lecz niskim poziomie. W 2012 r. stanowiła zaledwie 1,15\% PKB. Stopniowo wzrasta wielkość nakładów na B+R przypadających na 1 mieszkańca. 
Tabela 1. Podstawowe dane dotyczące działalności badawczo-rozwojowej w Brazylii w latach 2007-2012

\begin{tabular}{|l|c|c|c|c|}
\hline \multicolumn{1}{|c|}{ Wyszczególnienie } & 2007 & 2009 & 2011 & 2012 \\
\hline GERD (w PPS, mld dol.) & 23,9 & 26,1 & 30,2 & 31,3 \\
\hline $\begin{array}{l}\text { Udział w światowym GERD } \\
\text { (w \%) }\end{array}$ & 2,1 & 2,1 & 2,3 & 2,2 \\
\hline Relacja GERD do PKB (w \%) & 1,11 & 1,15 & 1,20 & 1,15 \\
\hline $\begin{array}{l}\text { GERD/mieszkańca } \\
\text { (w PPS, dol.) }\end{array}$ & 126,0 & 135,0 & 153,3 & 157,5 \\
\hline $\begin{array}{l}\text { GERD na pracownika naukowo- } \\
\text {-badawczego (w PPS, dol.) }\end{array}$ & 205,8 & 202,4 & $\begin{array}{r}210,5 \\
(2010)\end{array}$ & - \\
\hline
\end{tabular}

Źródło: zestawienie na podstawie danych zawartych w: [UNESCO 2015, s. 26-27].

W kraju tym zasadnicze znaczenie we wspieraniu działalności innowacyjnej ma sektor publiczny. Udział sektora publicznego w finansowaniu B+R stanowił 0,63\% w relacji do PKB [http://stats.oecd.org/]. Wzrasta także liczba pracowników naukowo-badawczych, w 2007 r. bowiem wynosiła 116,3 tys., a w 2010 r. 138,7 tys.; ma to odzwierciedlenie także w liczbie pracowników naukowo-badawczych przypadających na 1 mln mieszkańców (tab. 2).

Tabela 2. Dane dotyczące pracowników naukowo-badawczych w Brazylii w latach 2007-2010

\begin{tabular}{|l|c|c|c|}
\hline \multicolumn{1}{|c|}{ Dane } & 2007 & 2009 & 2010 \\
\hline Pracownicy naukowo-badawczy (w tys.) & 116,3 & 129,1 & 138,7 \\
\hline $\begin{array}{l}\text { Udział w światowej populacji pracowni- } \\
\text { ków naukowo-badawczych }\end{array}$ & 1,8 & 1,9 & 2,0 \\
\hline $\begin{array}{l}\text { Pracownicy naukowo-badawczy na 1 mln } \\
\text { mieszkańców }\end{array}$ & 612,0 & 667,2 & 710,3 \\
\hline
\end{tabular}

Źródło: [UNESCO 2015, s. 32-33].

Istniejący zasób pracowników naukowo-badawczych wciąż jest zbyt mały i występuje luka w zakresie zasobów ludzkich na rzecz B+R. Nastąpił także spadek liczby zatrudnionego personelu $\mathrm{B}+\mathrm{R}$ w sektorze przedsiębiorstw. Relatywnie niski jest udział sektora nierządowego w finansowaniu działalności B+R, który stanowił 0,52\% PKB w $2012 \mathrm{r}$. To przede wszystkim sektor przedsiębiorstw bierze udział we wspieraniu działalności $\mathrm{B}+\mathrm{R}$ w ramach sektora nierządowego. Wciąż niski udział sektora prywatnego $\mathrm{w}$ ponoszonych nakładach na innowacje wynika także z niskich umiejętności technicznych ludności. Wskazuje się również na brak zachęt stymulujących sektor prywatny do wprowadzania nowych produktów, technologii. Brazylijski system edukacji nie jest dostosowany do wymogów zmieniającego się środowiska zewnętrznego [UNESCO 2015, s. 216-219].

Inne dane dotyczące wyników realizowanej działalności badawczo-rozwojowej i innowacyjnej, pomimo stopniowej ich poprawy, wskazują na niski potencjał tego 
kraju. W Brazylii stopniowo wzrasta liczba publikacji naukowych - w 2008 r. wyniosła 28 244, a w 2014 r. 37 228, co oznacza zmianę o 31,8\%. Natomiast udział Brazylii w światowych publikacjach w 2014 r. stanowił zaledwie 2,9\%. Jeśli chodzi o liczbę publikacji na $1 \mathrm{mln}$ mieszkańców, to wyniosła $184 \mathrm{w} 2014$ r., podobnie jak w Argentynie (189), w RPA (175), natomiast w Niemczech 1109 na 1 mln mieszkańców przypadało publikacji. Niski jest stopień współpracy międzynarodowej prowadzonej przez brazylijskich naukowców odzwierciedlonej udziałem publikacji przygotowanych we współautorstwie, który wyniósł 33,5\% w 2014 r., a w 2008 r. stanowił zaledwie 25,6\%. W Argentynie wskaźnik ten stanowił 49,3\%, w RPA 60,5\%, w Niemczech 56,1\%, a w Chinach 23,6\% w 2014 r. [UNESCO 2015, s. 36]. Liczba wniosków patentowych z Brazylii złożonych do USPTO w 2008 r. wyniosła 142, a w 2013 r. 341 [UNESCO 2015, s. 38].

Innowacyjność przemysłu Brazylii jest niska nie tylko wśród krajów grupy BRICS, Ameryki Łacińskiej, ale także wśród krajów OECD. Jednakże w Brazylii występują także światowe firmy inwestujące w działalność B+R, w takich branżach, jak: wydobycie ropy naftowej na platformach wiertnicznych, przemysł lotniczy, inwestujące w bio- i nanotechnologie. Przedsiębiorstwa te są bardzo innowacyjne. Innowacyjne rozwiązania zastosowano również w rolnictwie. Niemniej brak jest konkurencyjnego wiodącego przedsiębiorstwa w ICT, elektronice czy też biotechnologii. Jest to także rezultatem prowadzonej polityki przemysłowej, która dotychczas chroniła rynek lokalnych producentów przed konkurencją z zewnątrz. Taki rynek, na którym działają tylko lokalni producenci, na ogół o niskiej konkurencyjności, nie sprzyja tworzeniu innowacyjnego środowiska, w którym powstają innowacje i następuje ich dyfuzja. W rezultacie przyczyniło się to także do spadku udziału Brazylii w handlu [OECD 2015, s. 79; UNESCO 2015, s. 219]. Podkreśla się zatem występowanie niskiej konkurencji na rynkach produktu jako przyczyny niskiej innowacyjności tego kraju [OECD 2015, s. 80].

Tabela 3. Dane dotyczące makroregionów w Brazylii (2011 r.)

\begin{tabular}{|l|c|c|c|}
\hline \multicolumn{1}{|c|}{ Makroregion } & $\begin{array}{c}\text { Udział w PKB } \\
\text { Brazylii (w \%) }\end{array}$ & $\begin{array}{c}\text { Dochód } \\
\text { na mieszkańca (R\$) }\end{array}$ & $\begin{array}{c}\text { Udział w przedsiębior- } \\
\text { stwach w kraju (w \%) }\end{array}$ \\
\hline Środkowozachodni & 9,6 & 27829 & 7,44 \\
\hline Północno-wschodni & 13,4 & 10379 & 15,7 \\
\hline Północny & 5,4 & 13888 & 3,58 \\
\hline Południowo-wschodni & 55,4 & 28350 & 51,83 \\
\hline Południowy & 16,2 & 24382 & 21,45 \\
\hline
\end{tabular}

Źródło: [Regional innovation..., s. 15].

Terytorium Brazylii jest podzielone na pięć makroregionów, bardzo zróżnicowanych, również pod względem społeczno-gospodarczym. Makroregiony obejmują 26 stanów i Dystrykt Federalny, a także 5570 gmin. Znaczne nierówności utrzymują się pod względem potencjału innowacyjnego. W makroregionie południowo- 
-wschodnim i południowym koncentruje się działalność przemysłowa i rozwój naukowy. Przede wszystkim wyróżnia się makroregion południowo-wschodni, w którym znajduje się stan São Paulo. W stanie tym następuje koncentracja działalności $\mathrm{B}+\mathrm{R}$ i o wysokiej zawartości wiedzy oraz miejsc pracy wymagających kwalifikacji [Regional innovation..., s. 15-16] (tab. 3).

Stan São Paulo zamieszkuje 22\% ludności Brazylii, a jego udział w tworzeniu PKB kraju stanowił 32\% i charakteryzował się podobnym udziałem w produkcji przemysłowej. W stanie tym koncentruje się działalność $B+R$, pochodzi $46 \%$ publicznych i prywatnych nakładów na $\mathrm{B}+\mathrm{R}$, jak również $66 \%$ nakładów na $\mathrm{B}+\mathrm{R}$ ponoszonych przez sektor przedsiębiorstw. Również inne wskaźniki potwierdzają główną rolę São Paulo w zakresie działalności B+R: w 2012 r. 41\% osób, które uzyskały stopień doktora, pochodziło z uniwersytetów z tego stanu, 44\% artykułów zostało przygotowanych przez brazylijskich autorów, z których przynajmniej jeden pochodził z instytucji z tego stanu, wzrasta także oddziaływanie publikacji przygotowanych przez naukowców $\mathrm{z}$ tego stanu. Jest to rezultatem dobrze finansowanego systemu publicznych uniwersytetów oraz roli, jaką odgrywa São Paulo Research Foundation [UNESCO 2015, s. 225].

\section{Kreowanie Narodowego Systemu Innowacji w Brazylii}

Koniec drugiej wojny światowej przyniósł istotne zmiany w Brazylii. W gospodarce kraju, będącej do tej pory dostawcą dóbr rolnych, stopniowo zaczęły dokonywać się przeobrażenia i wzrastać zaczęło znaczenie przemysłu (w latach 1950-1970). Wdrażano także politykę substytucji importu. Powstawały instytucje organizujące system nauki i techniki [Koeller, Cassiolato 2011, s. 37-38]. System badawczy w Brazylii w dużej mierze nie uległ zmianie od 1951 r., kiedy to została utworzona Narodowa Rada na rzecz Nauki i Rozwoju Technologicznego (National Council for Scientific and Technological Development - CNPq), powiązana z Ministerstwem Nauki, Techniki i Innowacji (MCTI). Ministerstwo to zostało utworzone w 1985 r. Postępująca prywatyzacja w latach 90. przyczyniła się także do prywatyzacji niektórych publicznych centrów badawczych w zakresie energii elektrycznej i dotyczących telekomunikacji. Funkcjonuje także FINEP - agencja innowacji odpowiedzialna za zarządzanie funduszem na rzecz finansowania innowacji: National Fund for Scientific and Technological Development (FNDCT) (1969 r.). Fundusz ten podlegał reformom od 1997 r., tworząc fundusze sektorowe generujące dochody, jak również zapewniając autonomiczne źródło dochodów dla FNDCT [Botelho 2012, s. 16; Koeller, Cassiolato 2011, s. 37-42]. FNDCT stanowi główne źródło finansowania badań uniwersytetów i szkolnictwa wyższego, którego zasobami zarządza FINEP, uzyskując także dodatkowe środki finansowe na własne działania i programy [http://rbi. ie/research-in-brazil/federal-funding/] (rys. 1).

Wspomnieć należy także o innych ministerstwach, które promują badania i innowacje, a są to: Ministerstwo Zdrowia nadzorujące Oswaldo Cruz Foundation, 


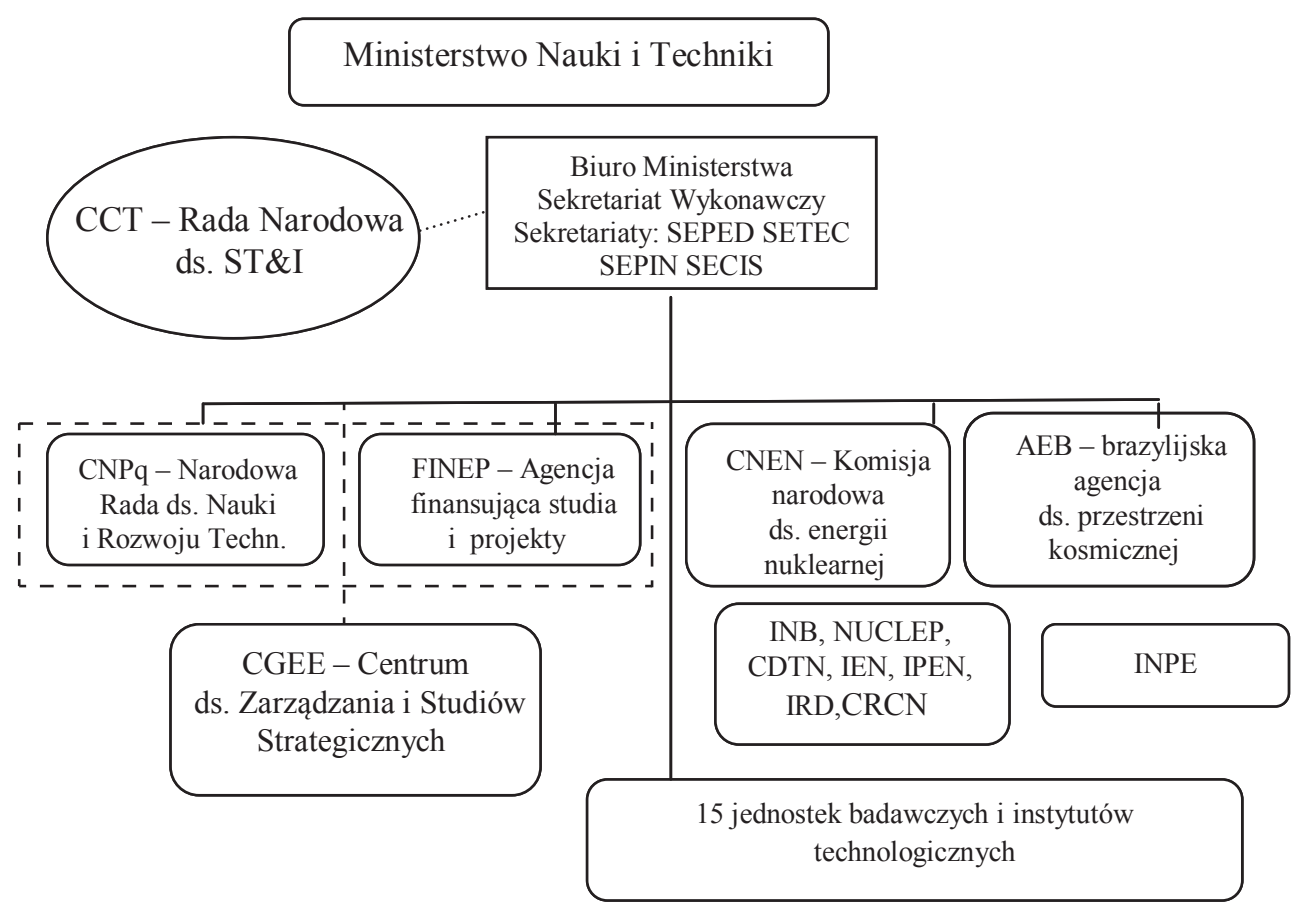

Objaśnienie: ST\&I - nauka, technika i innowacje; SEPED - polityka B+R i programy; SETEC - rozwój innowacji i technologii; SEPIN - polityka technologii informacyjnych; SECIS - nauka i technika na rzecz społecznej inkluzji; INPE - Narodowy Instytut ds. Badań Przestrzeni Kosmicznej; INB - Indústrias Nuvleares do Brasil S.A.; NUCLEP - Nuclebrás Equipamentos Pesados SA; CDTN - jednostka badawcza Centro de Desenvolvimento da Tecnologia Nuclear; IEN - Instytut ds. Inżynierii Nuklearnej; IPEN - Instytut ds. badań nuklearnych i energii; IRD - Instytut Ochrony Radiologicznej i Dozymentrii; CRCN - Regionalne Centrum Badań Nuklearnych.

Rys. 1. Struktura systemu zarządzania systemem badawczym w Brazylii

Źródło: „Structure of the Research System” in Brazil Country Fiche, za: [Botelho 2012, s. 17].

Ministerstwo Rolnictwa nadzorujące Brazilian Agricultural Research Cooperation (EMBRAPA). Ważną rolę odgrywa przedsiębiorstwo Petrobras będące głównym inwestorem w sferze B+R, mające własne centrum badawcze (CENPES) [http://rbi. ie/research-in-brazil/public-sector-research-organizations/].

\section{Programy na rzecz wspierania innowacyjności w Brazylii - wybrane aspekty}

W Brazylii wdrażane są programy na rzecz innowacyjności ze względu na ich znaczenie dla promowania wzrostu gospodarczego i przemian strukturalnych. W $2011 \mathrm{r}$. został wprowadzony plan Greater Brazil Plan 2011-2014, dotyczący polityki prze- 
mysłowej. Miał on na celu promowanie potencjału brazylijskich firm w zakresie rozwoju innowacyjnych produktów i usług oraz podniesienie ich umiejętności technologicznych. Plan PACTI obowiązywał w latach 2007-2010, a następnie została wprowadzona w grudniu 2011 r. Narodowa Strategia na rzecz Nauki, Techniki i Innowacji 2012-2015 (ENCTI). Poprzez podejmowane w ramach tej strategii działania ma zostać zapewniony rozwój zrównoważony. Główną siłą sprawczą zmierzającą do osiągnięcia tego celu są nauka, technika i innowacje. Strategia oparta jest na następujących trzech kluczowych elementach: promowanie innowacji, szkolenie zasobów ludzkich i budowanie potencjału, wzmacnianie badań w zakresie nauki i techniki i infrastruktury. Do priorytetów tego programu zaliczono następujące dziedziny: ICT, przemysł farmaceutyczny i opiekę zdrowotną, ropę i gaz, przemysł obronny, przestrzeń kosmiczną, energię jądrową, biotechnologię i nanotechnologię, promocję zielonej gospodarki, naukę, technologię i innowację na rzecz rozwoju społecznego [Botelho 2012, s. 13-14]. Wielkość środków finansowych przeznaczonych na wsparcie strategii wyniesie 21 mld euro ze środków rządowych, z innych zaś źródeł pochodzić będzie 10 mld euro (wsparcie finansowe z publicznych przedsiębiorstw, stanów federalnych) [http://rbi.ie/research-in-brazil/research-landscape-in-brazil/].

Poprzez działania realizowane $\mathrm{w}$ ramach tego programu narodowego mają zostać rozwiązane główne problemy wiążące się z innowacyjnością i dotyczące: zmniejszenia luki technologicznej dzielącej od gospodarek rozwiniętych, wsparcia przewodnictwa Brazylii w takich obszarach gospodarki wiedzy, które umożliwią wykorzystanie istniejących zasobów tego kraju, wzmocnienia internacjonalizacji narodowego systemu badań, promowania zielonej gospodarki, zmniejszenia istniejących nierówności społecznych i regionalnych [OECD 2015, s. 280].

Istotną kwestią do rozwiązania i zarazem do wdrożenia jest promowanie innowacyjności wśród przedsiębiorstw oraz wsparcie innowacji w celu rozwiązania problemów społecznych [OECD 2015, s. 280].

W celu wsparcia przedsiębiorstw wprowadzono odpowiednie regulacje prawne zachęcające przedsiębiorców do podejmowania działalności innowacyjnej (w 2004 r., w 2005 r.), dokonano modyfikacji zasad zwolnień podatkowych umożliwiających bezpośrednie wsparcie finansowe, jak również zachęcających przedsiębiorstwa do zaangażowanie się w innowacje. Ważne było także wprowadzenie w dniu 14 marca 2013 r. [OECD 2015, s. 280] Innovate Company Plan (Inova Empresa Plan) w celu poprawy konkurencyjności brazylijskich przedsiębiorstw na międzynarodowych rynkach. W ramach planu przewidziano cztery linie kredytowe na rzecz finansowania $\mathrm{B}+\mathrm{R}$, które dotyczyły: subsydiów dla przedsiębiorstw ( $\$ 1,2 \mathrm{mld})$, zachęt na rzecz tworzenia wspólnych projektów pomiędzy instytucjami badawczymi a korporacjami ( $\mathrm{R} \$ 4,2$ mld), udziałów w przedsiębiorstwach technologicznych (R $\$ 2,2$ mld) i pożyczek dla przedsiębiorstw, których raty podlegają subsydiowaniu (R\$ 20,0 mld). Agencjami wykonawczymi uczyniono: National Bank of Economic and Social Developement oraz FINEP. Na siedem strategicznych obszarów przezna- 
czono R \$23,5 mld i są nimi: rolnictwo i agrobiznes, energia, ropa, zdrowie, obrona, technologie ICT i środowiskowa podtrzymywalność. Pozostałe R 5 mld zostanie przeznaczone na inne obszary, w których funkcjonują przedsiębiorstwa, także małe. Natomiast środki finansowe w wysokości R \$ 4,4 mld zostaną przeznaczone na finansowanie innowacji w obszarach ropa i gaz oraz odnawialne źródła energii, a także wsparcie dla mikro- i małych przedsiębiorstw. Środki na ten kierunek wsparcia pochodzić będą od: National Petroleum Agency, National Electricity Agency, Brazilian Service of Support for Micro and Small Enterprises. Przewidziano dodatkowe środki na realizację planu z National Telecommunication Agency na rzecz wsparcia B+R w sektorze telekomunikacji [http://tradebridgeconsultants.com/news/ government/government-launches-new-innovation-plan/]. Zostało utworzone także Brazylijskie Przedsiębiorstwo ds. Badań w Przemyśle i Innowacji, stanowiące społeczną organizację usytuowaną przy MCTI i Ministerstwie Edukacji. Jeśli chodzi o jego działalność, to na podstawie konkursów udziela grantów niepodlegających zwrotowi na projekty przedsiębiorstw czy też instytucji [http://embrapii.org.br/dev/ en/about-us/]. Występują także inne społeczne organizacje: Institute for Pure and Applied Mathematics, Institute for the Sustainable Development, the National Centre for Research in Energy and Materials, Centre for Management and Strategic Studies, National Teaching and Research Network. Utworzenie pierwszych takich społecznych organizacji nastąpiło w $1998 \mathrm{r}$. i są to prywatne instytucje non-profit funkcjonujące na podstawie kontraktu $\mathrm{z}$ agencjami federalnymi, które zarządzają publicznymi zasobami badawczymi. Obecnie funkcjonuje sześć takich organizacji [UNESCO 2015, s. 212-213].

\section{Zakończenie}

W Brazylii dokonują się przemiany społeczno-gospodarcze, w rezultacie których poprawia się sytuacja mieszkańców tego kraju. Niemniej jednak jego potencjał innowacyjny jest niski, w świetle bowiem Globalnego Wskaźnika Innowacyjności 2015 kraj ten uplasował się na 70 miejscu, tuż za Omanem [The Global... 2015, s. 16]. Niska innowacyjność tego państwa jest również rezultatem uwarunkowań historycznych, które spowodowały, iż trudno jest obecnie poprawić pozycję Brazylii na globalnej scenie innowacji. Szczególnie istotne jest wykreowanie nowoczesnego sektora przemysłowego zdolnego do sprostania konkurencji na arenie międzynarodowej. Obecnie w podejmowanych działaniach zwraca się uwagę na zmniejszenie luki technologicznej dzielącej ten kraj od innych globalnych graczy, podkreśla się konieczność wzmocnienia innowacyjności przedsiębiorstw, jak również istotne staje się wykorzystanie innowacji do rozwiązania istniejących problemów społecznych. 


\section{Literatura}

Botelho A.J., Erawatch country reports 2012, Brazil, 2012, https://rio.jrc.ec.europa.eu/en/file/9021/ download?token=N5-X6YkD, 11.10.2016

http: //tradebridgeconsultants.com/news/government/government-launches-new-innovation-plan/, 20.03.2016.

http://data.worldbank.org/country/brazil, 20.03.2016.

http://embrapii.org.br/dev/en/about-us/, 20.03.2016.

http://rbi.ie/research-in-brazil/federal-funding/, 20.03.2016.

http://rbi.ie/research-in-brazil/public-sector-research-organizations/, 20.03.2016.

$\mathrm{http}: / / \mathrm{rbi}$.ie/research-in-brazil/research-landscape-in-brazil/, 20.03.2016.

http://stats.oecd.org/, 20.03.2016.

http://tradebridgeconsultants.com/news/government/government-launches-new-innovation-plan/,20.03.2016.

Koeller P., Cassiolato J. E., 2011, Achievements and Shortcomings of Brazil's Innovation Policies, [w:] BRICS and Development Alternatives. Innovation Systems and Policies, eds. J.E. Cassiolato, V. Vitorino, ANTHEM Press, London, New York, European Commission, s. 35-71.

OECD, 2014, OECD Science, Technology and Industry Outlook 2014, OECD Publishing, http://dx.doi. org.10.1787/sti_outlook-2014-en

OECD, 2015, OECD Economic Surveys: Brazil, OECD Publishing, Paris, http//dx.doi.org/10.1787/ eco_surveys-bra-2015-en.

Regional Innovation. Best practices in Competitiveness Strategy, 2014, Global Federation of Competitiveness Councils (http://www.thegfcc.org/sites/default/files/2014\%20Best\%20Practices.pdf, 19.03.2016).

The Global Innovation Index 2015. Effective innovation policies for development, 2015, Johnson Cornell University, INSEAD, WIPO, Fontainebleau, Ithaca and Geneva, https://www.globalinnovationindex.org/userfiles/file/reportpdf/gii-full-report-2015-v6.pdf, 19.03.2016.

UNESCO, 2015, Science Report. Towards 2030, UNESCO Publishing.

World Development Indicators, http://data.worldbank.org/country/brazil, 20.03.2016. 